
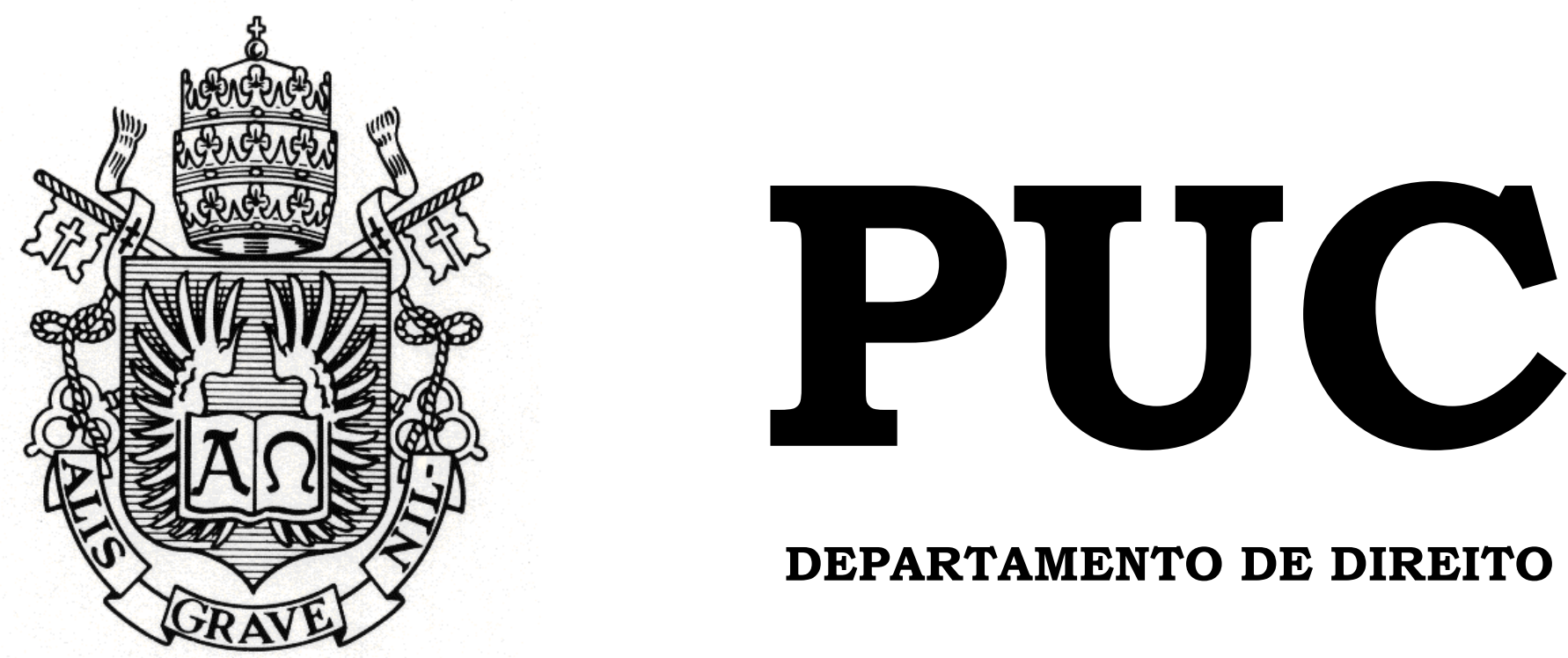

DEPARTAMENTO DE DIREITO

\title{
REMOÇÃO DE CONTEÚDO DA INTERNET: VIGILÂNCIA E PRIVACIDADE
}

por

LUCIANO KRSNAMURTI DA SILVA

ORIENTADORA: THAMIS ÁVILA DALSENTER VIVEIROS DE CASTRO

2017.1

PONTIFÍCIA UNIVERSIDADE CATÓLICA DO RIO DE JANEIRO

RUA MARQUÊS DE SÃO VICENTE, 225 - CEP 22453-900

RIO DE JANEIRO - BRASIL 


\section{REMOÇÃO DE CONTEÚDO DA INTERNET: VIGILÂNCIA E PRIVACIDADE}

por

\section{LUCIANO KRSNAMURTI DA SILVA}

Monografia

apresentada

ao

Departamento de Direito da Pontificia Universidade Católica do Rio de Janeiro (PUC-Rio) para a obtenção do Título de Bacharel em Direito.

Orientadora: Thamis Ávila Dalsenter Viveiros de Castro 
Palavras são, em minha nada humilde opinião, nossa inesgotável fonte de magia. Capazes de causar grandes sofrimentos e também de remediá-los.

Alvo Dumbledore 


\section{AGRADECIMENTOS}

Agradeço às amigas e aos amigos que fizeram parte dessa caminhada porque foram a família que pude escolher.

Ao Programa Universidade para Todos (ProUni), pela nobre função de equanimizar o acesso ao ensino superior a milhares de jovens como eu.

À PUC-Rio e ao CNPq, pelos diversos incentivos e oportunidades.

Aos mestres e mestras ímpares desta casa, pois, graças a vocês, tive a oportunidade de aprender todo dia um pouco mais.

Agradeço, em especial, às minhas orientadoras de monografia e de PIBIC, Thamis Dalsenter e Caitlin Mulholland. Vocês não existem!

Ao meu amor, Léo, por ser tão paciente, amigo e incrível.

Muito obrigado! 


\section{RESUMO}

A presente monografia pretende refletir sobre as implicações da remoção de conteúdo da internet à luz da Constituição, do Código Civil e de legislações extravagantes. Analisa desde os conceitos primários de privacidade e vigilância à responsabilidade pelos danos decorrentes da disponibilização destes dados pessoais na rede. Buscam-se a efetiva reparação da vítima, a reversão ao status quo ante bellum, em certa medida, e a correlata responsabilização de seu algoz.

Palavras-chave: Remoção de conteúdo - Privacidade - Dados pessoais Internet - Marco Civil - Vigilância - Censura - Liberdade de expressão Responsabilidade. 


\section{SUMÁRIO}

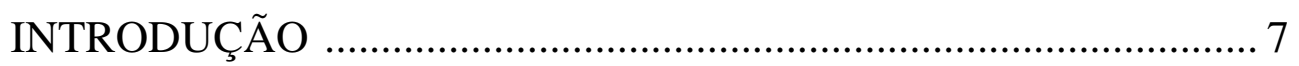

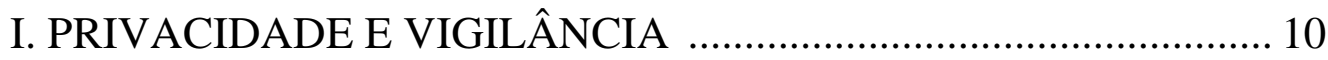

1.1 Contribuições ao direito à privacidade ........................................... 10

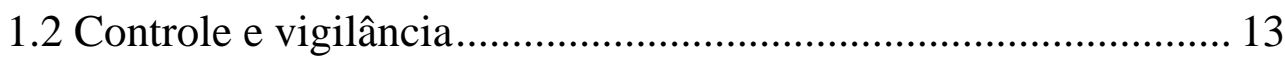

II. CONTEÚDO NA INTERNET: UM ACÚMULO DE DADOS ....... 16

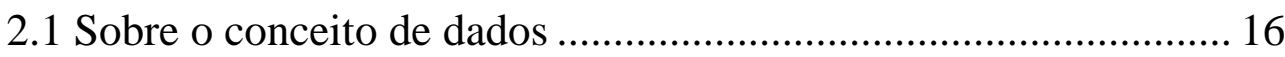

2.2 Marco Civil da Internet como contributo e a necessidade de regulamentar a proteção de dados no Brasil ....................................... 18

III. REMOÇÃO DE CONTEÚDO, UMA ANÁLISE SOBRE O ART.

19 DA LEI 12.965/2014 ................................................................ 23

3.1 Do direito de remover as próprias informações ............................ 23

3.2 Cotejo necessário entre censura e liberdade de expressão ............ 25

3.3 Limites entre a vida privada e o direito à informação .................... 27

3.4 Pressupostos à identificação e remoção do conteúdo..................... 30

3.5 A essencialidade da notificação judicial ........................................ 33

3.6 Notificação extrajudicial e seus aspectos ...................................... 34

IV. RESPONSABILIDADE CIVIL PELA PUBLICAÇÃO DE

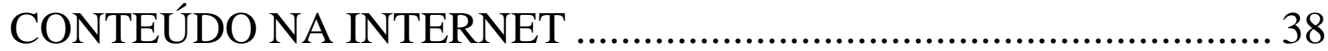

4.1 Distinções entre provedores de acesso, de conteúdo e de

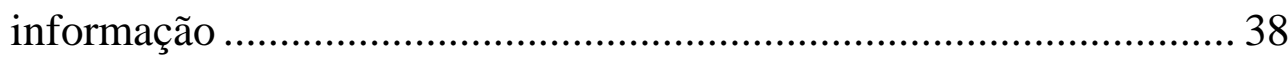

4.2 Da responsabilidade subsidiária do provedor de aplicações ......... 40

V. REMOÇÃO DE CONTEÚDO E SUA CONSOLIDAÇÃO NOS

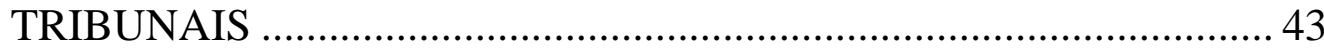

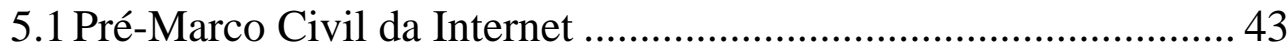

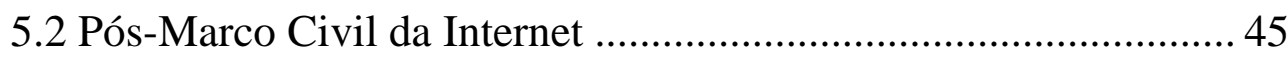

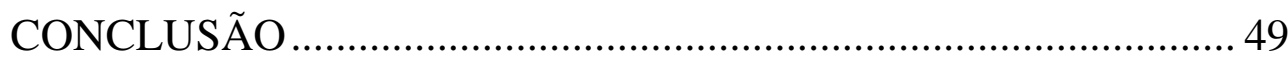

REFERÊNCIAS BIBLIOGRÁFICAS …............................................ 52 


\section{ABREVIATURAS}

AgRg - Agravo Regimental

AREsp - Agravo em Recurso Especial

AR-MP - Aviso de recebimento por mão própria

ART. - Artigo

CPC - Código de Processo Civil

CRFB/88 - Constituição da República Federativa do Brasil de 1988

Des. - Desembargador

DJE - Diário da Justiça Eletrônico

IP - Internet Protocol

ITS-Rio - Instituto de Tecnologia e Sociedade do Rio de Janeiro

Min. - Ministro

Mina. - Ministra

$\mathrm{N}^{\mathrm{o}}$. - Número

PL - Projeto de lei

Rel. - Relator

REsp - Recurso Especial

STJ - Superior Tribunal de Justiça

TJ-RJ - Tribunal de Justiça do Estado do Rio de Janeiro

URL - Universal Resource Locator

USP - Universidade de São Paulo 


\section{INTRODUÇÃO}

O desenvolvimento tecnológico cresce de forma exponencial e assustadora, isso é uma realidade. Estima-se que a quantidade de dados produzidos é duplicada a cada ano. Para se ter uma ideia, em 2016, a projeção de dados na rede corresponde ao equivalente à produção de dados em toda história da humanidade até $2015^{1}$.

A justificativa para a realização da presente monografia escora-se no crescimento das tecnologias e o aumento de dados pessoais circulando na rede. Diante desse cenário, é premente que o Direito oriente seus operadores e direcione as transformações relacionadas à internet. Mais que o arcabouço jurídico trazido pelo Marco Civil, é necessário conduzir o comportamento dos provedores de conteúdo na internet.

A ausência de regulamentação específica sobre dados pessoais e remoção de conteúdo, aliada à interpretação das normas já existentes em favor de provedores de conteúdo, contribui para violação de direitos fundamentais como a imagem, a honra e a privacidade.

O Direito deve responder de modo efetivo antes que tais inovações resultem em violações de direitos ainda mais severas. É preciso fortalecer os mecanismos legais já existentes para proteção do conteúdo disponibilizado na internet - principalmente o conteúdo capaz de devassar a privacidade em seu núcleo, de degradar a imagem e a honra do indivíduo.

A esse respeito, preleciona Gilmar Mendes:

Os avanços tecnológicos alcançaram uma dimensão tão distante da moldura jurídica com a qual trabalhamos que, em certa medida, talvez já nem seja mais correto falar-se, hoje, em insuficiência da legislação, no sentido de seu descompasso com as tecnologias de ingerência com as quais convivemos. [...] talvez seja hoje mais apropriado falar-se em ineficiência de todo um modelo de regulação fundado nas tradicionais garantias de inviolabilidade do domicílio e do sigilo das comunicações. Nesse sentido, poderíamos ampliar o campo de

\footnotetext{
1 "Will Democracy Survive Big Data and Artificial Intelligence"? Disponível em: < https://www.scientificamerican.com/article/will-democracy-survive-big-data-and-artificialintelligence/> Acesso em: 09 abr. 2017.
} 
observação para entender que estamos tratando aqui, na verdade, de uma clara ineficiência não só da legislação infraconstitucional, mas da própria base constitucional com a qual procuramos assegurar, muitas vezes em vão, efetiva proteção ao direito à privacidade ${ }^{2}$.

O cuidado com a publicação de um conteúdo pessoal torna-se uma máxima e, naquilo que couber, implicaria, inclusive, em sua remoção e a correspondente responsabilização ao causador direto do dano.

Este trabalho está dividido em introdução, cinco capítulos e conclusão, e estruturado na seguinte forma: a introdução aponta para o desenvolvimento da tecnologia e seus desdobramentos, destacando a importância de regulamentar a proteção dos dados pessoais, para que, quando necessário, a remoção de conteúdo pessoal seja efetiva.

O primeiro capítulo aborda a tutela da privacidade em sua raiz e evolução na tentativa de racionalizá-la, e caminha na direção do controle e da vigilância na sociedade informacional. Sobre a privacidade, tem-se o que aponta Danilo Doneda, a saber:

A tutela da privacidade é mais bem enquadrada dentro do que foi descrito por Pietro Perlingieri como uma situação subjetiva complexa, i.e., uma situação que não se expressa através do exercício arbitrário do poder pelo seu titular, porém em um complexo de interesses, tanto do titular quanto da coletividade, que pode dar origem a poderes bem como a deveres, obrigações, ônus aos envolvidos ${ }^{3}$.

O segundo desenvolve o conceito de dados pessoais, esculpindo a noção de dados sensíveis e a necessidade de proteção e cuidado ainda maiores.

O terceiro realiza uma análise sobre o art. 19 da lei 12.965/2014 Marco Civil da Internet -, confronta censura e liberdade de expressão, vida privada e direito à informação, além de elencar os pré-requisitos para identificação e remoção do conteúdo.

\footnotetext{
${ }^{2}$ MENDES, Gilmar Ferreira; BRANCO, Paulo Gustavo Gonet. Curso de direito constitucional. $9^{\mathrm{a}}$ ed. São Paulo: Saraiva. 2014, p.569.

${ }^{3}$ DONEDA, Danilo. Da privacidade à proteção de dados pessoais. Rio de Janeiro: Renovar, 2006, p.144.
} 
O quarto capítulo visa simplificar a distinção entre provedor de conexão e provedor de aplicações, a fim de que a responsabilidade sobre a remoção de conteúdo seja direcionada ao agente adequado.

$\mathrm{O}$ quinto traça o panorama do instituto da remoção e sua consolidação nas Cortes, assinalando a mudança e a evolução, por assim dizer, do tema, desde o período pré Marco Civil até a atualidade. Por fim, e não menos importante, uma seção dedicada à conclusão. 


\section{CAPÍTULO I - Privacidade e vigilância}

\subsection{Contribuições ao direito à privacidade}

O instituto da privacidade, assim como a ciência do Direito, experimentou, e ainda experimenta, inúmeras transformações. A atual noção de privacidade, a positivação do instituto em nosso ordenamento jurídico (Constituição Federal, Código Civil, Marco Civil da Internet, entre outras leis) e as relações em seu entorno são o resultado de um longo processo histórico.

Segundo Lewis Mumford (1953, p. 29), conforme citado por Rodotà (2007, p. 19), “A primeira mudança radical [...] destinada a modificar a forma da casa medieval foi o desenvolvimento do sentido de intimidade. Esta significava a possibilidade de afastar-se, por vontade própria, da vida e das atividades em comum" ${ }^{4}$.

Este fragmento sustenta que a privacidade se manifesta na dissociação, ainda na sociedade feudal, entre vida pública e privada, entre o lugar em que são construídas as relações familiares e o local de trabalho. Em que pese tenha sido este um marco significativo ao direito à privacidade, é oportuno frisar que seu desenvolvimento através dos séculos não é retilíneo, mas sim uma ruptura constante de paradigmas presentes na sociedade.

Embora hoje não mais se confundam propriedade e privacidade, esta nasce não como um direito inerente à pessoa humana, como um direito fundamental, e sim como prerrogativa de alguns níveis e classes da sociedade feudal ${ }^{5}$. Em outras palavras, significa dizer que o poderio econômico, garantidor de propriedades e prerrogativas, reservado a poucos, retirou o direito à privacidade da classe operária.

\footnotetext{
${ }^{4}$ RODOTÀ, Stefano. A Vida na Sociedade da Vigilância: a privacidade hoje. Maria Celina Bodin de Moraes (Org.). Rio de Janeiro: Renovar, 2007, p.19.

${ }^{5}$ RODOTÀ, 2007, p.20.
} 
A privacidade, gradativamente, se distanciou do ter, do possuir, da propriedade, assumindo a forma do ser, do sujeito enquanto pessoa humana. O direito à vida privada afasta-se da busca por tranquilidade, de ver-se livre da observação de outros indivíduos, do direito de ser deixado só, e aproxima-se do controle das informações sobre si mesmo, passando a figurar na classe dos direitos fundamentais ${ }^{6}$.

Stefano Rodotà, em sua obra "A vida na sociedade da vigilância", destaca, e o faz de maneira feliz, que a privacidade já não mais se confunde com propriedade ${ }^{7}$, não devendo reduzir sua complexidade à mínima da permissão (ou não) a terceiros sobre informações atinentes ao indivíduo singularizado.

No ordenamento jurídico pátrio, o direito à privacidade é reforçado em alguns momentos, ora pela $\mathrm{CRFB} / 88$, no art. $5^{\circ}, \mathrm{X}$ :

Art. $5^{\circ}$ Todos são iguais perante a lei, sem distinção de qualquer natureza, garantindo-se aos brasileiros e aos estrangeiros residentes no País a inviolabilidade do direito à vida, à liberdade, à igualdade, à segurança e à propriedade, nos termos seguintes:

$\mathrm{X}$ - são invioláveis a intimidade, a vida privada, a honra e a imagem das pessoas, assegurado o direito a indenização pelo dano material ou moral decorrente de sua violação;

Ora no Código Civil de 2002:

Art. 21. A vida privada da pessoa natural é inviolável, e o juiz, a requerimento do interessado, adotará as providências necessárias para impedir ou fazer cessar ato contrário a esta norma.

Embora positivado, o instituto da privacidade carece de interpretação, surgindo a necessidade de considerar não apenas a perspectiva individualista, mas levar em conta o viés coletivo. Nesta vereda, o raciocínio não parte do interesse do indivíduo, mas enquanto inserido em um determinado grupo.

\footnotetext{
${ }^{6}$ DONEDA, Op. cit., pp.7-9.

${ }^{7}$ RODOTÀ, 2007, p.19.
} 
Pensar no direito à vida privada sob o ponto de vista de apenas um indivíduo, per se, empalidece o instituto, seja por não compreender a totalidade, seja pela relação de disparidade de poder entre os usuários de uma plataforma digital e a empresa que mantém o funcionamento desta.

$\mathrm{O}$ direito à privacidade, assim como qualquer direito, não é em si absoluto. Em uma escala de valores e ponderações, "deveria ser garantido o máximo de opacidade às informações suscetíveis de originar práticas discriminatórias e o máximo de transparência àquelas que, referindo-se à esfera econômica dos sujeitos, concorrem para embasar decisões de relevância coletiva"».

Com efeito, o direito à vida privada migra do conceito de ser deixado só para uma premissa muito mais sensível, que é "o direito a controlar o uso que os outros façam das informações que me digam respeito [...], o direito do indivíduo de escolher aquilo que está disposto a revelar aos outros"9.

Acerca do controle e armazenamento de dados, assevera Gilmar Mendes:

Assunto bastante atual e ainda não suficientemente equacionado do ponto de vista dos riscos à privacidade diz respeito ao armazenamento de dados, debate que não se adstringe à mera proteção de dados armazenados em computadores pessoais, tendo em conta, cada vez mais, o vasto volume de informações de usuários de internet em poder dos provedores desse tipo de serviço. O tema vem ganhando notoriedade diante da possibilidade de acesso a esses dados, de forma ampla e irrestrita, por parte de autoridades públicas ${ }^{10}$.

Ora, a violação ao direito à privacidade não está sendo propriamente debatida com relação às páginas ou arquivos abertos no computador pessoal. Para além disso, o controle massivo das empresas de serviços na internet quanto à coleta, ao tratamento e ao armazenamento de dados pessoais, por meio de plataformas, sites e aplicações é o que de fato assusta.

\footnotetext{
${ }^{8}$ RODOTÀ, Op. cit., p.24.

${ }^{9}$ Ibid. p.50.

${ }^{10}$ MENDES, Gilmar Ferreira; BRANCO, Paulo Gustavo Gonet, 2014, p.567.
} 
A privacidade, pensada à luz do direito civil-constitucional, busca ser compreendida como o direito de possuir as rédeas sobre as próprias informações. E sob tal perspectiva, o consentimento do indivíduo sobre o uso de seus dados é tão essencial.

O Min. Gilmar Mendes sublinha que “(...) sem a privacidade, não há condições propícias para o desenvolvimento livre da personalidade. Estar submetido ao constante crivo da observância alheia dificulta o enfrentamento de novos desafios", e mais à frente complementa, " o termo 'vida privada' se estende para além do mero 'direito de viver como se quer, livre de publicidade, para incluir o direito de estabelecer e desenvolver relações (...) para o desenvolvimento da própria personalidade" ${ }^{11}$.

\subsection{Controle e vigilância}

"No regime totalitário imaginado por Orwell, a privacidade é uma aspiração quase impossível. Até mesmo as ideias e sonhos dos cidadãos são vigiados por uma Polícia do Pensamento"12, destaca Schreiber. A vida real imita a ficcional, porquanto em um universo de controle, cruzamento de dados e vigilância, o direito à privacidade é tão improvável quanto no livro, e a vida privada é cada vez mais devassada.

De acordo com André Nogueira:

A liberdade de expressão, o direito à informação, a proteção de dados e a neutralidade da rede, encontram resistência diante dos interesses de poderosos grupos econômicos e até mesmo do Estado, que enxerga cada vez mais na internet, a possibilidade de vigilância sobre os usuários, valendo-se, inclusive, do acesso aos seus dados ${ }^{13}$.

É cada vez mais evidente que estamos no centro de uma vigilância institucional. Em 2015, isto foi ainda mais reforçado quando da

\footnotetext{
${ }^{11}$ Ibid. pp.280-281.

${ }^{12}$ SCHREIBER, Anderson. Direitos da Personalidade. São Paulo: Atlas, 2013, p.133.

${ }^{13}$ NOGUEIRA, André Fontoura. Marco Civil da Internet: Desafios à sua efetivação entre a sociedade e o poder econômico, 2015, p.2. Acesso em 29 mar. 2017.
} 
publicização dos detalhes do programa do serviço secreto britânico "Karma Police", considerada a maior tentativa de monitoramento em massa do planeta $^{14}$. O Big Brother de Orwell estaria se tornando uma realidade?

Na China, a exemplo, planeja-se uma espécie de controle social. De acordo com relatórios recentes, cada cidadão chinês receberá uma pontuação capaz de determinar em que condições as pessoas podem realizar empréstimos, obter empregos ou visto de viagem para outros países. Este monitoramento individual incluiria até a navegação na internet das pessoas e o comportamento de suas relações na rede ${ }^{15}$.

Londres é outro exemplo, inclusive, por possuir a fama de ser a cidade mais vigiada do mundo, em razão das câmeras espalhadas em diversos locais públicos e privados da cidade. Entretanto, há fortes protestos por parte da sociedade contra o excesso de vigilância e controle ${ }^{16}$.

Rodotà se preocupa com a vida na sociedade informacional, por estar cada vez mais observada, e em suas palavras diz que todos estão sendo "assediados por computadores, espiados por olhos furtivos, filmados por telecâmeras invisíveis. Os cidadãos da sociedade da informação correm o risco de parecer homens de vidro: uma sociedade que a informática e a telemática estão tornando totalmente transparente" ${ }^{\text {"17. }}$.

As pessoas passaram a ser constantemente vigiadas, identificadas, catalogadas, inseridas no cenário em que a vigilância passa da condição de excepcional à cotidiana. Sustenta-se que a proteção de dados almejada traduz a expressão de liberdade e dignidade da pessoa humana, e "não se

\footnotetext{
14 Disponível em: <http://convergecom.com.br/teletime/25/09/2015/karma-police-e-mais-umescandalo-de-ciberespionagem/>. Acesso em 29 mar. 2017.

${ }_{15}$ Disponível em: <https://www.scientificamerican.com/article/will-democracy-survive-big-dataand-artificial-intelligence/>. Acesso em 29 mar. 2017.

${ }^{16}$ Disponível em: <http://www.bbc.co.uk/blogs/portuguese/esporte/2012/09/londres_cidade_proibi da.shtml>. Acesso em 29 mar. 2017.

${ }^{17}$ RODOTÀ, 2007, p.7.
} 
deve tolerar que um dado seja usado de modo a transformar um indivíduo em objeto sob vigilância constante"18.

Portanto, a questão não é sobre se preceitos fundamentais, como a privacidade, desde a concepção, devem ser aplicados para garantir o adequado desenvolvimento da personalidade e frear os abusos do poder público, e sim de que maneira.

${ }^{18}$ Ibid. p.8. 


\section{CAPÍTULO II - Conteúdo na internet: um acúmulo de dados}

\subsection{Sobre o conceito de dados}

Aplicações e plataformas digitais são cada vez mais utilizadas pelos usuários. E, na proporção em que esses espaços virtuais são ocupados, a coleta, o tratamento e o armazenamento de dados pessoais crescem exponencialmente.

Dado pessoal é todo dado capaz de revelar a identidade de uma pessoa ${ }^{19}$. Logo, "se uma determinada informação está relacionada a uma pessoa identificada ou identificável”20, trata-se de um dado pessoal.

O art. $5^{\circ}$, I, do PL n ${ }^{\circ} .5 .276$ de $2016^{21}$, em tramitação na Câmara dos Deputados, estabelece que dado pessoal é todo "dado relacionado à pessoa natural identificada ou identificável, inclusive números identificativos, dados locacionais ou identificadores eletrônicos quando estes estiverem relacionados a uma pessoa"22.

O PL acerta na definição de dado pessoal porque engloba os dados que, embora não identifiquem imediatamente uma pessoa natural, estão relacionados a ela, podendo eventualmente identificá-la. Desse modo, ainda que diversos dados pessoais estejam dispersos, ainda assim é possível associá-los ao seu titular.

Dado pessoal é gênero que se subdivide em duas espécies: dados cadastrais e dados sensíveis. Dados cadastrais são informações que individualizam uma pessoa sem esbarrar em aspectos de sua privacidade,

\footnotetext{
${ }^{19}$ BIONI, Bruno Ricardo. Xeque-mate: o tripé de proteção de dados pessoais no xadrez das iniciativas legislativas no Brasil, 2015, p.25.

${ }^{20}$ Ibid. p.4.

${ }^{21}$ O PL n ${ }^{\circ}$. 5.276/2016 dispõe sobre o tratamento de dados pessoais para a garantia do livre desenvolvimento da personalidade e da dignidade da pessoa natural. O PL foi apensado ao PL 4060/20012, que aguarda a constituição de uma comissão temporária pela Mesa da Câmara. Disponível em: < http://www.camara.gov.br/proposicoesWeb/fichadetramitacao?idProposicao $=20$ 84378>. Acesso em 21 mar. 2017. Texto original.

${ }^{22}$ O que são dados pessoais? Disponível em: <http://www.internetlab.org.br/pt/opiniao/especial-oque-sao-dados-pessoais/>. Acesso em 16 mar. 2017.
} 
como nome e o número da cédula de identidade, que não dependem de uma decisão judicial para serem acessadas pelas autoridades administrativas que possuam competência para requerê-las.

O Marco Civil da Internet decide, em seu art. 10, caput e $\S 3^{\circ}$, que:

Art. 10. A guarda e a disponibilização dos registros de conexão e de acesso a aplicações de internet de que trata esta Lei, bem como de dados pessoais e do conteúdo de comunicações privadas, devem atender à preservação da intimidade, da vida privada, da honra e da imagem das partes direta ou indiretamente envolvidas.

§ 3o O disposto no caput não impede o acesso aos dados cadastrais que informem qualificação pessoal, filiação e endereço, na forma da lei, pelas autoridades administrativas que detenham competência legal para a sua requisição.

Como complemento ao Marco Civil, o PL 5.276/16 adentra no mérito sobre dados sensíveis - aquelas informações que demandam uma proteção adicional porque, além de identificar uma pessoa, carregam características íntimas que podem ensejar situações discriminatórias.

Rodotà ressalta que "a proteção especial atribuída a estes dados não se justifica somente por se referirem a fatos íntimos, mas também, e às vezes sobretudo, pelo risco que seu conhecimento possa provocar discriminações" ${ }^{23}$.

Acerca dos dados sensíveis, o PL orienta:

Art. $5^{\circ}$. Para os fins desta Lei, considera-se:

III - Dados sensíveis: dados pessoais sobre a origem racial ou étnica, as convicções religiosas, as opiniões políticas, a filiação a sindicatos ou a organizações de caráter religioso, filosófico ou político, dados referentes à saúde ou à vida sexual e dados genéticos ou biométricos ${ }^{24}$.

Ainda que a privacidade tenha tomado outras cores, como o direito à utilização e ao controle das próprias informações, não deve ser compreendida sob a perspectiva de cada dado pessoal, ou de cada indivíduo.

${ }^{23}$ RODOTÀ, Op. cit., p.70.

${ }^{24} \mathrm{PL} \mathrm{n}{ }^{\circ} .5 .276 / 2016$. 
A obtenção de um número de telefone, um endereço residencial ou um e-mail, vista de forma fragmentada, pode até parecer inofensiva. No entanto, "reunindo-se um conjunto de informações disponíveis sobre certa pessoa, é possível classificar tais informações de acordo com critérios estipulados pelo organizador dos dados para construir 'perfis' de consumidores, segurados, empregados, devedores e assim por diante" ${ }^{25}$.

Nas palavras de Anderson Schreiber, "o direito à privacidade abrange, hoje, não apenas a proteção à vida íntima do indivíduo, mas também a proteção de seus dados pessoais" 26 .

Portanto, o direito à privacidade alcança os ambientes em que circulam os dados pessoais, sejam os que dizem respeito a características físicas, econômicas, sejam aqueles relacionados ao estado de saúde do indivíduo. Complementa Schreiber que "a privacidade pode ser definida sinteticamente como o direito ao controle da coleta e da utilização dos próprios dados pessoais" 27 .

\subsection{Marco Civil da Internet como contributo e a necessidade de regulamentar a proteção de dados no Brasil}

Em que pesem os avanços trazidos pelo Marco Civil da Internet em 2014, o Brasil é o único país da América Latina que ainda não possui um mecanismo específico que tutele a proteção de dados pessoais. Conta-se com normas genéricas que não resguardam de forma efetiva os direitos relativos a informações pessoais ${ }^{28}$.

O PL 5.276/16, sobre proteção de dados pessoais, tem o objetivo de assegurar ao cidadão a gerência das próprias informações, garantindo assim a tutela do direito à privacidade e o desenvolvimento da personalidade.

\footnotetext{
${ }^{25}$ SCHREIBER, Op. cit., p.137.

${ }^{26}$ SCHREIBER, Op. cit., p. 136.

${ }^{27}$ Ibid. p. 137.

${ }^{28}$ MACHADO, Joana de Moraes Souza. A tutela da privacidade no controle de dados pessoais no Direito brasileiro, Revista Arquivo Jurídico, Teresina, v.2, n.2, p. 53, Jul/Dez de 2015.
} 
Note-se que em uma sociedade informacional, dados pessoais são valiosos, atraem empresas e, portanto, demandam uma tutela específica.

Sancionado o PL, este orientará a interpretação das prescrições presentes no Marco Civil. Isto porque limites são necessários à norma geral, evitando espaços capazes de vulnerabilizar a vida privada.

Por ser exclusivo ao próprio sujeito o direito de autorizar o uso das próprias informações, o PL exige o consentimento expresso para coleta, tratamento e armazenamento. Por meio do consentimento, o direito civil garante a autonomia da vontade, princípio que reside na "liberdade de, em conformidade com a lei, celebrar negócios jurídicos, criando direitos e contraindo obrigações" 29 .

A redação do projeto, além de tratar de diversos requisitos indispensáveis à coleta, ao tratamento e ao armazenamento de dados imprescindível o consentimento livre, informado e inequívoco fornecido pelo titular -, elenca deveres de quem realiza o tratamento de dados pessoais, assim sendo:

As pessoas que realizam o tratamento de dados pessoais têm o dever de informar de maneira clara e explícita ao titular dos dados: a finalidade para a qual os seus dados estão sendo coletados e de que forma serão tratados; a identidade e o domicílio do responsável pelo tratamento; a natureza obrigatória ou facultativa do fornecimento de dados; os sujeitos para os quais os dados podem ser comunicados e os seus direitos, em particular a possibilidade de se negar a fornecer tais dados e sobre seu direito de acesso e retificação dos mesmos ${ }^{30}$.

Mesmo que o usuário fique privado de uma relação negocial, isto é, não obtenha acesso a determinados bens e serviços, é fundamental escolher revelar ou não suas informações pessoais, a fim de exercer seu poder de autodeterminação.

Por exemplo, um consumidor em potencial que deseja realizar uma compra na internet e, para tanto, deve preencher um cadastro. Entretanto, há

\footnotetext{
${ }^{29}$ GONÇALVES, Carlos Roberto. Direito Civil Brasileiro - Parte Geral. São Paulo: Saraiva, 2012, p.350.

${ }^{30}$ MACHADO, Joana. Op. cit., p.56.
} 
seções nos questionários que não dizem respeito exatamente com a compra, ou seja, os considerados dados sensíveis. $O$ não preenchimento o impossibilitará de realizar a compra, pela ausência de informações pessoais consideradas relevantes.

Por padrão, não restam opções para o usuário da aplicação, ou aceita a conceder as informações necessárias ou não celebra o contrato.

O PL, adiante, ressalta que:

Art. $6^{\circ}$. As atividades de tratamento de dados pessoais deverão observar a boa-fé e os seguintes princípios:

III - necessidade: pelo qual o tratamento deve se limitar ao mínimo necessário para a realização das suas finalidades, abrangendo dados pertinentes, proporcionais e não excessivos em relação às finalidades do tratamento de $\operatorname{dados}^{31}$.

Uma plataforma de e-commerce não necessita de dados pessoais de um indivíduo como a orientação sexual, registro e/ou endereço profissional, número de filhos ou hábitos ligados à saúde para realizar a venda de um produto ou prestar um serviço. A razão disso é que a coleta de dados, como anuncia o dispositivo acima, deve se limitar ao mínimo necessário para que o receptor realize suas finalidades, abrangendo somente os dados pertinentes e não excessivos.

Não se trata de um consentimento negocial, mas de aquiescência inequívoca para coleta e tratamento de dados pessoais. Trata-se de um desdobramento da própria autonomia da vontade, que permite ao indivíduo o pleno exercício dos direitos da personalidade. A coleta e o tratamento de dados pessoais, que não foram autorizados pelo seu titular, configuram atos unilaterais e abusivos, ensejando a remoção do conteúdo da base de dados onde foram armazenados.

Outro aspecto abordado pelo projeto é a interconexão ou cruzamento dos dados pessoais entre plataformas, redes sociais e empresas. Este

\footnotetext{
${ }^{31} \mathrm{PL} \mathrm{n}^{\circ} .5 .276 / 2016$.
} 
cruzamento só poderá ser realizado com a permissão do seu titular, sendo um consentimento perfeitamente revogável a qualquer tempo.

Em princípio, uma plataforma não pode ceder informações a terceiros para finalidades incompatíveis com o que foi previamente estabelecido, cujo consentimento foi concedido expressamente. Senão vejamos outros dois princípios:

Art. $6^{\circ}$.

I - finalidade: pelo qual o tratamento deve ser realizado para finalidades legítimas, específicas, explícitas e informadas ao titular, não podendo ser tratados posteriormente de forma incompatível com essas finalidades;

II - adequação: pelo qual o tratamento deve ser compatível com as suas finalidades e com as legítimas expectativas do titular, de acordo com o contexto do tratamento ${ }^{32}$.

O titular também deve ser informado sobre o tratamento de seus dados, em consonância com o art. $8^{\circ}$ do PL $n^{\circ}$. 5.276/2016 no que tangencia (i) a finalidade específica do tratamento; (ii) sua forma e duração; (iii) identificação precisa do responsável pela coleta e tratamento; (iv) informações que possibilitem o contato com o responsável; (v) sujeitos ou categorias para os quais os dados podem ser transmitidos; (vi) delimitação da responsabilidade do provedor de serviços de internet ${ }^{33}$; (vii) menção explícita dos direitos que o titular dos dados possui, quais sejam o acesso às próprias informações, bem como a devida retificação destas, a possibilidade de não fornecer o consentimento ou revogá-lo, por meio de procedimento gratuito, e de realizar denúncia ao órgão competente caso necessário.

Em síntese, ainda que as finalidades sejam similares àquelas para as quais os dados foram coletados, ainda assim, haverá necessidade do consentimento do titular. A solução para o problema é simples: após a utilização dos dados, estes deverão ser excluídos quando não houver mais serventia, podendo ser removidos por intermédio de um serviço de

\footnotetext{
${ }^{32} \mathrm{PL} \mathrm{n}^{\circ}$. 5.276/2016.

${ }^{33}$ LEONARDI, Marcel. Responsabilidade civil dos provedores de serviços de internet. São Paulo: Juarez de Oliveira, 2005, p.19.
} 
atendimento ao consumidor na própria plataforma ou, na hipótese de resistência, por via judicial.

Deduz-se, assim, que a regulamentação da proteção de dados pessoais é necessária, pois concede aos usuários o embasamento legal para o exercício da remoção de conteúdo da internet - seja o conteúdo sensível publicado em uma plataforma provedora de conteúdo, seja o conjunto de informações coletadas sem o consentimento de seu titular. 


\section{CAPÍTULO III - Remoção de conteúdo, uma análise sobre o Art. 19 da Lei 12.965/2014}

\subsection{Do direito de remover as próprias informações}

$\mathrm{O}$ direito à privacidade em diversas constituições é formalizado pelo instituto do Habeas Data, embora pouco utilizado no Brasil. O objetivo desse remédio constitucional é possibilitar a modificação, a remoção ou a correção de informações em razão de sua natureza, seja ela sensível, difamatória ou discriminatória.

$\mathrm{Na}$ internet, controvérsias relativas à privacidade eram resolvidas com a condenação por danos patrimoniais, e agora também por meio da notice and takedown ${ }^{34}$, contra quem armazena as informações.

Enquanto o direito ao esquecimento ${ }^{35}$, a rigor, desindexa determinados termos ou frases ${ }^{36}$, a remoção indisponibiliza, total ou parcialmente, a depender do pedido, os dados sensíveis de um usuário. Enquanto a remoção implica em exclusão dos dados, a desindexação, em obstáculo ao acesso a eles, porque apenas dificulta, não impede.

A remoção de conteúdo é o instrumento por meio do qual o titular dos dados exerce um direito personalíssimo e, por essa razão, há que se falar nas características dos direitos da personalidade.

Nessa senda, o Código Civil de 2002, em seu art. 11, prevê duas delas:

Art. 11. Com exceção dos casos previstos em lei, os direitos da personalidade são intransmissíveis e irrenunciáveis, não podendo o seu exercício sofrer limitação voluntária.

\footnotetext{
${ }^{34}$ Em linhas gerais, notice and takedown significa que o provedor de conteúdo não será responsabilizado, em primeiro plano, pela publicação indevida se, após notificado pelo titular das informações, removê-lo de pronto.

${ }^{35}$ Direito ao esquecimento é a possibilidade, em alguns casos, de exigir a buscadores quem dificultem o acesso de informações pessoais por outras pessoas por meio da desindexação.

${ }^{36}$ Significa suprimir ou generalizar determinados termos ou palavras de um texto, documento ou post.
} 
Além de intransmissíveis e irrenunciáveis, são (i) essenciais, porque transcendem a positivação normativa; (ii) originais, por serem inatos à pessoa humana; (iii) vitalícios, pois acompanham a pessoa durante toda a vida; (iv) possuem oponibilidade erga omnes, podendo ser exercidos contra todos; (v) são extrapatrimoniais, porquanto, via de regra, não têm natureza econômica; (vi) imprescritíveis, podendo sempre ser exercidos, embora o direito à reparação sujeite-se aos prazos prescricionais; (vii) impenhoráveis, haja vista a essencialidade desses direitos, não podendo servir de garantia ${ }^{37}$.

Sobre o exercício de um direito da personalidade, no caso, a proteção da privacidade, o art. 12 do Código Civil prevê:

Art. 12. Pode-se exigir que cesse a ameaça, ou a lesão, a direito da personalidade, e reclamar perdas e danos, sem prejuízo de outras sanções previstas em lei.

Portanto, tem legitimidade ad causam para fazer cessar tal violação o próprio titular, haja vista o caráter personalíssimo do instituto ${ }^{38}$.

Contudo, em se tratando de titular morto, tem legitimidade para requerer a medida - no caso, a remoção do conteúdo - o cônjuge sobrevivente, qualquer parente em linha reta, ou colateral até o quarto grau. Assim aduz o parágrafo único do mesmo dispositivo:

Parágrafo único. Em se tratando de morto, terá legitimação para requerer a medida prevista neste artigo o cônjuge sobrevivente, ou qualquer parente em linha reta, ou colateral até o quarto grau.

No julgamento do REsp no. 1.005.278/SE, o Min. Luis Felipe Salomão reforça a previsão acima:

Assim, em se tratando de pessoa morta, como no caso presente, os herdeiros indicados e o cônjuge sobrevivente são legitimados para buscar o ressarcimento/indenização decorrente de lesão. Como bem salientou o Ministro Antônio de Pádua Ribeiro, no julgamento do REsp 11.735/PR (2ª Turma, DJ de

\footnotetext{
37 SILVA, R.B. "Sistema protetivo dos direitos da personalidade". In: SILVA, R.B.; SANTOS, M.J. (orgs). Responsabilidade Civil na internet e nos demais meios de comunicação. São Paulo: Saraiva, 2007, pp.18-20.

${ }^{38}$ BDINE JÚNIOR, H. C. "Responsabilidade civil do veículo de comunicação por atos próprios". In: SILVA, R.B.; SANTOS, M.J. (orgs). Responsabilidade Civil na internet e nos demais meios de comunicação. São Paulo: Saraiva, 2007, p. 434.
} 
13.12.1993), "o direito de ação por dano moral é de natureza patrimonial e, como tal, transmite-se aos sucessores da vítima". Bem por isso, não cabe falar em limitação ao direito dos legitimados de obterem a cessação da lesão e reclamar indenização mesmo quando o fato tenha ocorrido após a sua morte. (REsp $n^{\circ}$. 1.005.278/SE, Rel. Min. LUIS FELIPE SALOMÃO, QUARTA TURMA, julgado em 04/11/2010, DJe 11/11/2010)

O REsp interposto do acórdão do Tribunal de Justiça de Sergipe, em ação indenizatória por danos morais e uso indevido da imagem movida pelo cônjuge sobrevivente, cuidou da reparação do dano causado por um Jornal que publicou, sem autorização, a fotografia do de cujus, marido da autora, sete dias após o acidente. Em paralelo, se o material tivesse sido publicado em site da internet, gozaria da mesma legitimidade para, nesse caso, remover o conteúdo.

\subsection{Cotejo necessário entre censura e liberdade de expressão}

A internet modificou as relações sociais e a forma de comunicação entre as pessoas, trazendo novos desafios para a comunidade jurídica. Com o objetivo de ponderar um desses, o Marco Civil da Internet prescreve:

Art. 19. Com o intuito de assegurar a liberdade de expressão e impedir a censura, o provedor de aplicações de internet somente poderá ser responsabilizado civilmente por danos decorrentes de conteúdo gerado por terceiros se, após ordem judicial específica, não tomar as providências para, no âmbito e nos limites técnicos do seu serviço e dentro do prazo assinalado, tornar indisponível o conteúdo do apontado como infringente, ressalvadas as disposições legais em contrário.

Diferente de outrora, em que as palavras eram lançadas ao vento, hoje, uma vez disponibilizado, o conteúdo toma um rumo imprevisível. Com a sociedade cada vez mais globalizada, as informações circulam de forma cada vez mais rápida. Nas palavras de Ronaldo Lemos, "lidar com 
esse desafio de forma construtiva e democrática é uma das tarefas mais importantes do nosso século" 39 .

É desafiador porque a remoção de conteúdo da internet e, mais especificamente, o direito à privacidade encontram seus limites na liberdade de expressão e na vedação à censura prévia. O Marco Civil da Internet, neste aspecto, claramente, prestigia a liberdade de expressão.

$\mathrm{O}$ art. 19 da lei garante que o provedor de aplicações de internet só pode ser responsabilizado civilmente, por danos decorrentes de conteúdo, após ordem judicial específica e se, somente se, não tomar as devidas providências.

Nesse raciocínio, esclarece o Min. Luis Felipe Salomão:

[...] não se afirma que há dano moral imputável ao provedor de internet (administrador de rede social), já no momento em que determinada mensagem é postada na rede. Nesse momento, há o dever de o provedor retirar tal mensagem do seu ambiente virtual, mas sua responsabilização civil vai depender de sua conduta, se omissiva ou não, levando-se em conta a proporção entre sua culpa e o dano experimentado por terceiros (art. 944, parágrafo único, do CPC/73). (REsp 1175675/RS, Rel. Min. LUIS FELIPE SALOMÃO, QUARTA TURMA, julgado em 09/08/2011, DJe 20/09/2011)

A tendência adotada pelo magistrado não é novidade alguma já que tal metodologia é aplicada nos EUA, onde se cunhou a expressão notificação e retirada (em inglês, notice and takedown).

A rigor, blogs, buscadores, sites em geral disponibilizam ferramentas para remoção de conteúdo, funcionando, desta forma, como um serviço de atendimento ao usuário. O problema é quando a plataforma ignora a reclamação, por assim dizer, quando não considera violador o conteúdo.

Da mesma forma que a plataforma pode não considerar o conteúdo violador, o inverso também pode ocorrer. O administrador do serviço que remove de imediato um conteúdo, por considera-lo transgressor às políticas

\footnotetext{
${ }^{39}$ LEMOS, Ronaldo. Ofensas na internet não justificam censura, Revista Tribuna do Advogado, Rio de Janeiro, n. 561, p.16, Out de 2016.
} 
e termos de uso, por vezes negligencia as especificidades da publicação e incorre em censura prévia.

Um caso recente, ocorrido em abril de 2015, ilustra bem o pano de fundo: o Ministério da Cultura publicou, em sua página oficial do Facebook, a foto de um casal de indígenas botocudos, em que a mulher aparecia com os seios despidos. No dia seguinte, véspera do Dia do índio, o Facebook bloqueou a publicação, por ter limitações em relação à nudez. Isto tudo gerou polêmica acerca dos padrões da comunidade frente ao direito de liberdade de expressão.

O Ministério da Cultura entendeu que houve censura ao bloquear a imagem, ferindo a Constituição, o Marco Civil da Internet, o Estatuto do Índio, entre outras normas. O Ministro titular da pasta completou dizendo: "se os índios não podem aparecer como são, o recado que fica é que precisam se travestir de não-indígenas para serem reconhecidos. Isso é de uma crueldade sem fim". O conteúdo acabou sendo republicado e, como resposta, o Facebook sublinhou a dificuldade em equilibrar liberdade de expressão com a experiência confortável em uma rede social ${ }^{40}$.

Outro caso de censura prévia, envolvendo o Facebook por remoção de conteúdo, foi a retirada da foto histórica da guerra do Vietnã, em que uma menina corre nua para fugir de um ataque com um agente inflamável ${ }^{41}$. Em resposta, o Facebook diz ter o algoritmo entendido que, por se tratar de uma foto de uma criança nua, houve a remoção sem atentar à carga histórica da imagem.

\subsection{Limites entre a vida privada e o direito à informação}

\footnotetext{
40 Disponível em: < http://g1.globo.com/politica/noticia/2015/04/facebook-diz-que-desbloqueouimagem-de-india-com-seios-expostos.html>. Acesso em 23 mar. 2017.

${ }^{41}$ Disponível em: < http://oglobo.globo.com/sociedade/tecnologia/facebook-retira-foto-historicado-ar-gera-debate-sobre-limites-na-selecao-de-conteudos-20083096>. Acesso em 29 mar. 2017.
} 
A remoção de conteúdo da internet encontra desafios não apenas em ajustar liberdade de expressão e censura, mas também na esfera da privacidade e o direito à informação, à pesquisa histórica e científica.

Nas eleições municipais de 2016, diversos candidatos a prefeito e vereador, espalhados pelo Brasil, ingressaram com, aproximadamente, 600 ações judiciais pedindo a suspensão, o bloqueio, a interrupção na circulação de jornais ou retiradas de informações pessoais em sites.

O ponto reside na supressão das informações com a escusa no direito à privacidade. Ora, "em posse dessas informações, a sociedade pode entender o que está acontecendo e cobrar das pessoas públicas que fazem uso desse instrumento judicial para censurar algum tipo de conteúdo" 42 .

A coordenadora-geral de projetos do Instituto de Tecnologia e Sociedade do Rio de Janeiro (ITS-Rio), Celina Bottino, salienta que "pela natureza da função, pessoas públicas têm o direito à privacidade mais restrito. A difamação é um crime tipificado, mas é um pouco genérico, pois trata de fato ofensivo à reputação. Mas, e se este fato for de interesse público?"’3

Como já apresentado, a internet traz desafios vários, mas, nas palavras de Ronaldo Lemos, deve-se lembrar que:

A melhor reação a um discurso ou relato considerado problemático é a resposta a ele na esfera pública. Em vez de supressão ou tolhimento, mais discursos, mais versões, mais contraditório. Essa é a praxe saudável de uma sociedade que se governa sob um Estado democrático de Direito ${ }^{44}$.

Em outras palavras, se a informação não é verdadeira, em vez de solicitar a remoção do conteúdo, o agente político deve ir a público dar sua versão, oferecer mais fatos, para que seus eleitores cheguem a uma conclusão de forma livre.

\footnotetext{
${ }^{42}$ MENDES, Nádia. É proibido publicar, Revista Tribuna do Advogado, Rio de Janeiro, n. 563, p.30, Fev. de 2017.

${ }^{43} \mathrm{Ibid}$. p.31.

${ }^{44}$ LEMOS, 2016, p.17.
} 
É evidente que cada conjuntura demanda lentes diferentes para ser observada, compreendida. Em se tratando da relação entre representantes do povo e representados, prevalecem o direito à informação e o fortalecimento da democracia. Quando o alvo é uma pessoa não pública, não parece razoável priorizar o direito à sociedade de obter informações que dizem respeito única e exclusivamente àquela pessoa. Daí porque a necessidade de uma lei que assegure o direito à proteção destas informações. Neste caso, aplicar-se-ia o dispositivo do PL de proteção de dados pessoais ${ }^{45}$ segundo o qual:

Art. 16. Os dados pessoais serão eliminados após o término de seu tratamento, autorizada a conservação para as seguintes finalidades:

I - cumprimento de obrigação legal do responsável; II - pesquisa histórica, científica ou estatística, garantida, quando possível, a anonimização dos dados pessoais; ou III - transferência a terceiros, desde que respeitados os requisitos de tratamento de dados dispostos nesta Lei.

Em se tratando de pessoa não pública, ausente a autorização para o armazenamento das informações pessoais, estas devem ser removidas após seu tratamento, conforme a previsão do dispositivo acima. Já nos casos em que a discussão versar sobre dados sensíveis, o Marco Civil da Internet estabelece que:

Art. $19, \S 3^{\circ}$. As causas que versem sobre ressarcimento por danos decorrentes de conteúdos disponibilizados na internet relacionados à honra, à reputação ou a direitos de personalidade, bem como sobre a indisponibilização desses conteúdos por provedores de aplicações de internet, poderão ser apresentadas perante os juizados especiais.

A figura do juizado especial no artigo pretende simplificar o procedimento, prezando pela informalidade, oralidade e celeridade, além de estreitar a relação entre a sociedade e o judiciário, entre outros princípios observados na Lei 9.099/95 e na CRFB/88.

\footnotetext{
${ }^{45} \mathrm{PL} \mathrm{n}^{\circ} .5 .276 / 2016$.
} 
As causas iniciadas nos juizados tendem a fluir de forma mais rápida - já que não se admite a produção de prova pericial, bem como um limite de 40 salários mínimos para o valor da causa. A contrapartida é a possibilidade, no procedimento comum, de realização de provas por vezes fundamentais à demonstração do direito, possibilitando um valor maior de indenização.

Percebe-se que, de maneira geral, a remoção do conteúdo é realizada como a última medida, sempre alinhada a princípios constitucionais, como o direito à privacidade. Trata-se do direito de controlar as próprias informações, de apagar eventos pretéritos que não dizem respeito a mais ninguém, e não um instituto incompatível com o direito à informação. Remover certos conteúdos significa dar a possibilidade ao titular dos dados de reescrever a própria história.

\subsection{Pressupostos à identificação e remoção do conteúdo}

O Marco Civil da Internet em consonância com o Código de Processo Civil de 2015 no tocante a um dos pressupostos da petição inicial: o pedido. Segundo as lições de Fredie Didier Jr, “o pedido há de ser certo (art. 322, CPC), determinado (art. 324, CPC), claro (art. 330, § $1^{\circ}$, II, CPC) e coerente (art. 330, §1 $\left.1^{\circ}, \mathrm{IV}, \mathrm{CPC}\right){ }^{\prime 46}$. Destaca também que:

Pedido certo é pedido expresso [...] não se admite, como regra, o pedido implícito. [...] Pedido determinado é aquele delimitado em relação à qualidade e à quantidade. Pedido determinado se contrapõe ao pedido genérico. [...] O pedido tem também de ser claro, inteligível. Pedido que se tenha sido formulado de maneira pouco clara implica inépcia da petição inicial, consoante já examinado. O pedido há, enfim, de ser coerente, ou seja, deve ser consequência jurídica prevista para a causa de pedir aduzida. Pedido que não decorre da causa de pedir implica inépcia da petição inicial, também como já examinado ${ }^{47}$.

\footnotetext{
${ }^{46}$ DIDIER JR., Fredie. Curso de Direito Processual Civil. 17ed. v. 1. Salvador: Juspodivm, 2015, p.566.

${ }^{47}$ Ibid. p.566.
} 
No entanto, garante que "na falta de um desses requisitos, deve o magistrado, antes de indeferir a petição inicial, determinar a sua correção $\left(\operatorname{art.~321)}{ }^{\prime 48}\right.$.

Sobre a delimitação precisa do pedido, in casu, a remoção de um conteúdo específico, um link, uma imagem ou o que quer que seja, o art. 19, $\S 1^{\circ}$, do Marco Civil da Internet, determina que:

A ordem judicial de que trata o caput deverá conter, sob pena de nulidade, identificação clara e específica do conteúdo apontado como infringente, que permita a localização inequívoca do material.

Neste sentido, o referido autor corrobora o dispositivo mencionado quando pede que se "note que os requisitos do pedido (certeza, determinação, clareza e coerência) são os mesmos requisitos da sentença. Se o pedido é um projeto de sentença, nada mais razoável do que exigir dessa os mesmos requisitos exigidos daquele" ${ }^{\prime 49}$.

No REsp n ${ }^{\circ}$. 1.406.448/RJ, a Mina. Nancy Andrighi, relatora do caso Geraldo do Carmo versus Google Brasil, em que pese tenha reconhecido o dever do Google de providenciar a remoção de conteúdo a partir de notificação dos usuários, isto é, dispensada a ordem judicial, o pedido de remoção deve ser certo e determinado ${ }^{50}$ - e por pedido certo e determinado entenda-se, nas palavras de Didier Jr., pedido claro e expresso.

De outra maneira, o interessado deve informar de forma clara e específica a respectiva URL ${ }^{51}$. Esta indica o caminho exato até determinado conteúdo na internet, permitindo chegar ao post que se considera lesivo. A indicação da URL é tão essencial que, sem ela, não é possível ao provedor a exclusão com eficiência de um determinado post, impedindo-o, por consequência lógica, de dar cabo ao pedido de remoção.

\footnotetext{
${ }^{48}$ Ibid. p.567.

${ }^{49}$ Ibid. p.567.

50 REsp 1406448/RJ, Rel. Mina. NANCY ANDRIGHI, TERCEIRA TURMA, julgado em 15/10/2013, DJe 21/10/2013.

${ }^{51}$ Localizador Uniforme de Recursos. Em inglês, Universal Resource Locator.
} 
Ainda no mesmo REsp n ${ }^{\circ}$. 1.406.448/RJ, a Ministra orienta que não há, no ramo da inteligência artificial, a possibilidade de que os computadores desenvolvam raciocínios subjetivos. Sendo assim, não é possível incumbir às máquinas a tarefa de dizer se determinado conteúdo possui ou não conteúdo ilícito, menos ainda se este conteúdo é ou não ofensivo a uma pessoa. E acrescenta:

\begin{abstract}
Não se pode ignorar, nesse aspecto, que, além de serem criados diariamente inúmeros blogs, são também inseridos milhares de posts, sendo certo que, diferentemente das máquinas, o ser humano é criativo e sagaz, de sorte que encontraria meios de burlar esses critérios, por intermédio da utilização de termos ou expressões semelhantes ou equivalentes que, repise-se, não serão identificadas pela limitada capacidade de raciocínio dos computadores ${ }^{52}$.
\end{abstract}

De mais a mais, o conteúdo pode ser ressignificado, recodificado ou escrito de diversas formas de modo a não ser identificado e removido pela aplicação. Essa é a principal justificativa para indicar a URL, para então limitar e determinar o pedido.

Além da identificação precisa do local do conteúdo que se pretende remover, não é possível responsabilizar o provedor sem saber quem foi o autor direto da ofensa. Em contrapartida, o art. $5^{\circ}$, IV, da CRFB/88, garante a liberdade de manifestação do pensamento, ao mesmo tempo em que veda o anonimato. Trocando em miúdos, qualquer um pode se expressar, desde que se identifique.

Nesta linha, o provedor deve oferecer um serviço que permita aos usuários utilizarem a internet nos moldes de esfera pública, como espaço para propagar ideias. Também é seu dever viabilizar a identificação de cada um destes usuários, atribuindo a cada manifestação uma autoria certa e determinada - assim como devem ser o pedido e a decisão judicial.

A valer, os provedores que facilitam o cadastro de seus usuários por qualquer motivo, optando por não exercer um controle mínimo de seus filiados, assumem o risco da desídia, respondendo subsidiariamente pelos

\footnotetext{
${ }^{52}$ REsp 1406448/RJ.
} 
danos causados a terceiros. Ou seja, a responsabilidade pelo conteúdo gerado recai, a priori, sobre aquele que diretamente realiza a conduta danosa. A rigor, o provedor não será responsabilizado pela mera inclusão de conteúdo por terceiros, mas em caso de não realizar o controle mínimo, assume o risco do descuido.

\subsection{A essencialidade da notificação judicial}

Além da indicação precisa do exato teor infringente por meio da URL, isto é, a identificação clara e específica do conteúdo a ser removido, bem como apontar o autor da ofensa, mostra-se essencial a avaliação de um juiz. Portanto, surge a notificação judicial como requisito formal para responsabilizar o provedor de internet ${ }^{53}$.

Antes do Marco Civil, o judiciário considerava que a mera notificação extrajudicial, indicando ao provedor de internet sobre a existência de uma transgressão, já seria suficiente para indicar sua responsabilidade subsidiária em caso de descumprimento.

A justificativa de a lei exigir a notificação judicial parece estar no fato de que não seria possível existir um filtro que valorasse previa ou repressivamente o que viola ou não a intimidade de uma pessoa. E, ainda que isso fosse possível, a análise e a eventual remoção do conteúdo ficariam ao alvitre do provedor - como o caso da publicação bloqueada da página do Ministério da Cultura. Nessa linha, é imprescindível que o juiz avalie, pois, nas palavras de Marcel Leonardi:

Não se trata aqui de dizer se o conteúdo é legal ou ilegal, mas, sim, de saber quem detém a competência técnica e jurídica para determinar isso. É natural que os advogados que representam vítimas que se sentem ofendidas com algum tipo de conteúdo reclamem que as plataformas têm de exigir essa remoção

\footnotetext{
${ }^{53}$ MULHOLLAND, Caitlin. Responsabilidade civil indireta dos provedores de serviço de internet e sua regulação no marco civil da internet, XXIV Encontro Nacional do CONPEDI - UFS Direito e novas tecnologias, Aracaju, p. 493, Jun de 2015. Disponível em: 〈http://www.conpedi.org.br/publicacoes/c178h0tg/vwk790q7/dTa7488W12NDA0SJ.pdf >. Acesso em 28 mar. 2017.
} 
imediatamente. Mas, o ponto é que, na maioria dos casos, como a jurisprudência, inclusive, reconhece, saber se a ilegalidade do conteúdo é algo que existe ou não é extremamente subjetivo, que depende da avaliação de quem detém competência técnica para isso, que é o Estado, o juiz ${ }^{54}$.

Sustenta-se que a necessidade do crivo judicial é indispensável porque a notificação extrajudicial, contingentemente, dá azo à remoção de conteúdo arbitrária com fundamento em uma denúncia simples realizada pelo interessado sem o devido processo legal, nem uma investigação mais incisiva, ou ao menos a possibilidade do contraditório.

\subsection{Notificação extrajudicial e seus aspectos}

Nos casos em que a divulgação de um conteúdo ${ }^{55}$, ausente o consentimento de seus participantes, viole a intimidade destes, o provedor de aplicações, quando, depois de receber a notificação extrajudicial pelo participante ou seu representante legal, deixar de providenciar, de forma responsável e eficaz, a indisponibilidade deste conteúdo, incorrerá em responsabilidade por eventuais danos materiais e morais.

É claro que se objeto violar a intimidade e ineficaz tenha sido o pedido extrajudicial, o demandante poderá levar ao conhecimento do judiciário, apresentando ao juizado especial, a fim de receber uma solução mais célere. Outra alternativa para obter o pedido judicial é de forma preliminar, por meio de uma cautelar, desde que presentes dois elementos: $o$ fumus boni iuris e o periculum in mora.

O pêndulo do Marco Civil está, de fato, voltado para liberdade de expressão, e não para a privacidade, já que a notificação judicial é tratada como regra. No entanto, em se tratando de violação da intimidade por

\footnotetext{
${ }^{54}$ Audiência pública, no Senado Federal, para debater o PL da Câmara 21/2014 que veio a ser o Marco Civil da Internet.

${ }^{55} \mathrm{Na}$ inteligência do art. 21 do Marco Civil da Internet, como imagens, vídeos ou outros materiais contendo cenas de nudez ou de atos sexuais de caráter privado.
} 
disponibilização de imagens, vídeos ou de outros materiais contendo nudez ou atos sexuais, as regras são modificadas, senão vejamos:

Art. 21. O provedor de aplicações de internet que disponibilize conteúdo gerado por terceiros será responsabilizado subsidiariamente pela violação da intimidade decorrente da divulgação, sem autorização de seus participantes, de imagens, de vídeos ou de outros materiais contendo cenas de nudez ou de atos sexuais de caráter privado quando, após o recebimento de notificação pelo participante ou seu representante legal, deixar de promover, de forma diligente, no âmbito e nos limites técnicos do seu serviço, a indisponibilização desse conteúdo.

Não se espera, é claro, que a plataforma realize todo o trabalho sozinha, pois cabe ao interessado a identificação específica e clara do material ora apontado como violador da intimidade, possuindo legitimidade ad causam para tanto. É o que reza o parágrafo único, do art. 21, do mesmo diploma legal:

Parágrafo único. A notificação prevista no caput deverá conter, sob pena de nulidade, elementos que permitam a identificação específica do material apontado como violador da intimidade do participante e a verificação da legitimidade para apresentação do pedido.

Por notificação extrajudicial ${ }^{56}$, entende-se aquela realizada via Cartório de Títulos e Documentos, pelo correio (através de correspondência via AR-MP), ou até mesmo por meio de algum mecanismo disponível na própria plataforma.

O Google, a título de exemplo, em sua aplicação Maps, permite a possibilidade de desfocar ou remover fotos realizadas em $360^{\circ}$ pela empresa ${ }^{57}$. Por meio da ferramenta, o próprio usuário, sem precisar valer-se do Judiciário, pode desfocar, na imagem capturada pelo carro da empresa, seu rosto ou de alguém de sua família, ou quaisquer outras informações que violem sua intimidade. $\mathrm{O}$ recurso não está disponível em computadores,

\footnotetext{
${ }^{56}$ O Código de Processo Civil, lei 13.105/2015, delimita a noção de notificação no art. 726, quando diz que "quem tiver interesse em manifestar formalmente sua vontade a outrem sobre assunto juridicamente relevante poderá notificar pessoas participantes da mesma relação jurídica para dar-lhes ciência de seu propósito".

${ }^{57}$ Disponível em: <https://support.google.com/maps/answer/7011973?co=GENIE.Platform\%3D

Desktop\&hl=pt-BR>. Acesso em 30 mar. 2017.
} 
mas tão somente no aplicativo do Street View. Uma vez realizado o procedimento pelo usuário, não existe a possibilidade de revertê-lo.

Desde quando o Google criou, em 2010, o Transparency Report ${ }^{58}$, mais de um terço das solicitações de remoção citavam difamação como fundamento ${ }^{59}$. Isto é, $28 \%$ das solicitações do governo mencionavam a palavra "difamação" como motivo, $17 \%$ citavam "privacidade e segurança", e apenas $15 \%$ "segurança nacional".

Em 2014, o Tribunal de Justiça da União Europeia determinou que cada indivíduo possui o direito de solicitar a buscadores, como o Google, a remoção de certos resultados sobre si mesmo. Também decidiu que, além da avaliação sobre a solicitação de remoção, os buscadores podem continuar a exibir tão somente os resultados nos casos em que houver interesse público. ${ }^{60}$

No mesmo ano, o Google recebeu dos cidadãos europeus indicações de 1.963.386 URLs a serem removidas, dentre 704.314 solicitações. Ou seja, 3 URLs, em média, por solicitação/pessoa. Ainda nesse cenário, a empresa, efetivamente, removeu $43,2 \%$ do conteúdo apontado como violador à honra, à privacidade, ou à segurança.

Esse panorama só reforça o quanto os indivíduos não possuem o controle das próprias informações porque estão sob o domínio do provedor de serviços, seja um buscador como o Google, seja um provedor de conteúdo, como um jornal.

Antes do Marco Civil da Internet, a pessoa lesada notificava extrajudicialmente o provedor do material, este, por sua vez, realizaria um juízo de valor sobre a fundamentação trazida e, a depender da avaliação, o

\footnotetext{
${ }^{58}$ Plataforma que analisa os pedidos de remoção de conteúdo e disponibiliza em tempo real a situação dos produtos do Google ao redor do mundo. Disponível em: < https://www.google.com/transparencyreport/?hl=pt-BR>. Acesso em 30 mar. 2017.

59 Disponível em: < https://www.google.com/transparencyreport/removals/government/?hl=ptBR>. Acesso em 30 mar. 2017.

${ }^{60}$ Disponível em: < https://www.google.com/transparencyreport/removals/europeprivacy/?hl=ptBR>. Acesso em 30 mar. 2017.
} 
conteúdo era removido ou não. Se o provedor retirasse o conteúdo, poderia responder perante o usuário, mas se em contrapartida não o removesse, poderia responder subsidiariamente pelos danos ${ }^{61}$.

Com o advento do Marco Civil, essa análise pelo provedor é desnecessária, porquanto a obrigação de remover o conteúdo nasce a partir da ordem judicial. No entanto, em relação ao material que contenha cenas de nudez, não há a necessidade de ordem judicial, tão somente a mera notificação extrajudicial.

Do ponto de vista do titular dos dados, o Marco Civil da Internet, além de não regular toda a remoção de conteúdo, dificultou o panorama, uma vez que, em diversos casos, o conteúdo podia ser removido através de notificação extrajudicial, e hoje somente com decisão judicial.

Também não inovou quando previu, em seu art. $19, \S 3^{\circ}$ e $4^{\circ}$, sobre o ingresso em juizados especiais, bem como em relação à tutela de urgência requerida em caráter antecedente, haja vista a disponibilidade destes mecanismos no CPC de 1973, e também no de 2015.

Portanto, fica evidente a opção do legislador por prestigiar mais a liberdade de expressão, e um pouco menos o direito à privacidade. E a questão é: a liberdade de expressão e o direito à informação não são absolutos, isto é, não são preceitos fundamentais mais importantes que o direito à privacidade.

61 Disponível em: <http://www.conjur.com.br/2014-set-10/sistema-retirada-conteudo-internetpiorou-marco-civil>. Acesso em 30 mar. 2017. 


\section{CAPÍTULO IV - Responsabilidade civil pela publicação de conteúdo na internet}

\subsection{Distinção entre provedores de acesso, de conteúdo e de informação}

Para compreender a remoção de dados da internet em todo o seu alcance, é essencial definir, conforme a lei e a jurisprudência, quem é o responsável pelo conteúdo. O capítulo se concentra em determinar quem integrará o polo passivo da demanda, quem poderá ser convocado a responder pelos danos causados aos titulares das informações circuladas. Antes disso, é necessário realizar algumas distinções entre provedor de conexão e de aplicações.

Embora "provedor de serviços de internet" seja um termo amplo, aceito tanto pela doutrina, quanto pela jurisprudência, tecnicamente, precisa ser esmiuçado. Para Marcel Leonardi, é provedor de serviços de internet "a pessoa natural ou jurídica que fornece serviços relacionados ao funcionamento da internet, ou por meio dela" ${ }^{\prime 2}$.

Dentro do conceito de provedor de serviços (gênero), três categorias são relevantes para delimitar a responsabilidade civil pela publicação de conteúdo na internet. Leonardi ${ }^{63}$ anota que:

Provedor de acesso é a pessoa jurídica fornecedora de serviços que consistem em possibilitar o acesso de seus consumidores à Internet.

Por outro lado, entende que:

Provedor de conteúdo é toda pessoa natural ou jurídica que disponibiliza na Internet as informações criadas ou desenvolvidas pelos provedores de informação, utilizando servidores próprios ou os serviços de um provedor de hospedagem para armazená-las.

Sobre a criação do conteúdo, destacou, ainda, o autor que:

\footnotetext{
62 LEONARDI, Op. cit., p.19.

${ }^{63}$ LEONARDI, MARCEL. "Responsabilidade dos provedores de serviços de internet por atos de terceiros". In: SILVA, R.B.; SANTOS, M.J. (orgs). Responsabilidade Civil na internet e nos demais meios de comunicação. São Paulo: Saraiva, 2007, p. 160.
} 
Provedor de informação, que é toda pessoa natural ou jurídica responsável pela criação das informações divulgadas na Internet, ou seja, o efetivo autor da informação disponibilizada por um provedor de conteúdo.

O art. 18 do Marco Civil é categórico em desonerar o provedor de conexão da responsabilidade civil por danos decorrentes de conteúdo gerado por terceiros.

Art. 18. O provedor de conexão à internet não será responsabilizado civilmente por danos decorrentes de conteúdo gerado por terceiros.

O provedor de conexão apenas permite que o usuário acesse a internet, estando isento de qualquer responsabilidade decorrente de conteúdo gerado e transmitido por usuários ou por terceiros.

$\mathrm{Na}$ verdade, o próprio autor do conteúdo publicado, no caso, o provedor de informação, deve ser responsabilizado pela compensação dos danos ${ }^{64}$. O art. 927, do Código Civil, atribui ao causador do dano o dever de reparação:

Art. 927. Aquele que, por ato ilícito (arts. 186 e 187), causar dano a outrem, fica obrigado a repará-lo.

Portanto, aquele que comete ato ilícito, violando direito e causando danos a outrem, fica obrigado a repará-lo.

O provedor de conexão, ainda que ligado a uma rede de fornecimento, não deve ser responsabilizado pela não remoção do conteúdo, uma vez não dispor de meios para controlar a atividade conduzida por terceiros que acessam a rede. $O$ provedor de conexão limita-se a fornecer a infraestrutura utilizada pelos usuários. Como já observado, a provedoria de conexão é um serviço instrumental, de meio, não de fim. Portanto, não faz parte do risco do negócio - de provedoria de acesso à internet - o controle de conteúdo gerado por outrem.

\footnotetext{
${ }^{64}$ MULHOLLAND, 2015, p.484.
} 
O provedor de aplicações é a empresa ou pessoa natural que fornece funcionalidades que podem ser utilizadas pelos usuários da internet. Dentro desse grupo de aplicações, temos os provedores de busca (Google e o Yahoo), hospedagem (UOL), correio eletrônico (Hotmail), além da provedoria de conteúdo (desde blogs pessoais a jornais).

Quanto à distinção entre conexão e aplicações, o art. $5^{\circ}, \mathrm{V}$, do Marco Civil traz alguns conceitos técnicos. Senão vejamos:

V- conexão à internet é a habilitação de um terminal para envio e recebimento de pacotes de dados pela internet, mediante a atribuição ou autenticação de um endereço IP.

Sobre aplicações de internet, o inciso VI determina que:

VI- aplicações de internet são o conjunto de funcionalidades que podem ser acessadas por meio de um terminal conectado à internet.

Deste modo, enquanto se sustenta que provedoria de conexão é o instrumento para alcançar as funcionalidades disponíveis na rede mundial de computadores, as aplicações são as próprias funcionalidades, isto é, o conteúdo, a busca, a hospedagem, o e-mail, por exemplo ${ }^{65}$.

\subsection{Da responsabilidade subsidiária do provedor de aplicações}

Com clareza e mostrando a que veio, o Marco Civil assegura a liberdade de expressão. Ao passo que o art. 18 exclui a responsabilidade civil do provedor de conexão, na sequência, o 19 determina que o provedor de aplicações somente será responsabilizado após ordem judicial específica - isso, é claro, caso não remova o conteúdo apontado como infringente dentro do prazo determinado:

Art. 19. Com o intuito de assegurar a liberdade de expressão e impedir a censura, o provedor de aplicações de internet somente poderá ser responsabilizado civilmente por danos decorrentes de conteúdo gerado por terceiros se, após ordem

${ }^{65}$ Ibid. p.483. 
judicial específica, não tomar as providências para, no âmbito e nos limites técnicos do seu serviço e dentro do prazo assinalado, tornar indisponível o conteúdo apontado como infringente, ressalvadas as disposições legais em contrário.

A rigor, o provedor de aplicações não é responsabilizado, porquanto a remoção antecipada do conteúdo configuraria censura prévia - o que indica que a possibilidade de responsabilização do provedor de aplicações ocorre em caráter excepcionalíssimo.

Apesar de inexistir ao provedor de conteúdo o dever de verificar previamente e impedir a publicação do material postado por terceiros, aquele poderá ser responsabilizado legalmente caso sejam cumpridos, cumulativamente, os requisitos a seguir: (i) o próprio que alega ter sofrido violação ao seu direito deve realizar o pedido de notificação judicial; (ii) o juiz entender pela procedência do pedido quanto à potencial lesividade da conduta daquele que inseriu o conteúdo; (iii) decisão judicial concedendo notificação ao provedor de aplicações, desde que o interessado tenha indicado o conteúdo específico; (iv) descumprimento da decisão pelo provedor $^{66}$.

Destaca-se que, somente se presentes os quatro requisitos, será possível responsabilizar, subsidiariamente, o provedor de aplicações, haja vista a possibilidade de atribuir a responsabilidade direta àquele que insere o conteúdo, o autor de fato. No fim, é o descumprimento da decisão judicial que enseja responsabilidade ao provedor.

Em se tratando de responsabilidade subsidiária, cumpre ressaltar que um terceiro, que não tenha agido ilicitamente, é responsável por quem agiu $^{67}$. É possível observar a responsabilidade subsidiária seja quando o empregador responde pelos danos causados por seus empregados durante a realização dos serviços, seja na relação entre provedor de aplicações e terceiros.

\footnotetext{
${ }^{66}$ MULHOLLAND, Op. cit., pp.486-487.

${ }^{67}$ CAVALIERI FILHO, Sergio, Programa de Responsabilidade Civil. São Paulo: Atlas, 2014, p.235.
} 
Dizer que se aplica o instituto da responsabilidade subsidiária, significa obrigar-se a indenizar o dano independentemente de culpa. A responsabilidade é objetiva, decorre da lei. Por natureza da responsabilidade subsidiária do provedor, entende-se que este responderá por quem publicar ou produzir o conteúdo, isto é, do autor direto. Desta maneira, a responsabilidade, inicialmente, é do provedor da informação que causou a violação à esfera privada de outro indivíduo pela criação do material, enquanto o provedor de conteúdo apenas responde na hipótese de descumprimento da ordem judicial.

A responsabilidade civil aplicada à remoção de conteúdo fez parte de um longo processo de construção. A exemplo, antes do Marco Civil, a Mina. Nancy Andrighi entendia que "ao ser comunicado de que determinado texto ou imagem possui conteúdo ilícito, deve o provedor agir de forma enérgica, retirando o material do ar imediatamente, sob pena de responder solidariamente com o autor direto do dano, em virtude da omissão praticada" ${ }^{\prime 6}$. Hoje, entende-se como regra a responsabilidade subsidiária.

Em apertada síntese, pretende-se responsabilizar, por padrão, o provedor da informação, ou seja, o criador do conteúdo publicado. Mas, na análise do caso, o juiz poderá responsabilizar subsidiariamente o provedor do conteúdo (quem instrumentaliza o conteúdo, embora não seja o criador de fato) em três situações: (i) se o provedor de conteúdo realizava um controle editorial prévio sobre as informações, um jornal por exemplo, e, ainda assim, publica o conteúdo danoso; (ii) quando deixar de remover um dado sensível, independentemente de notificação judicial, na forma do art. 21, do Marco Civil; (iii) se descumpre ordem judicial determinando a retirada do conteúdo.

${ }^{68}$ REsp 1192208/MG, Rel. Mina. NANCY ANDRIGHI, TERCEIRA TURMA, julgado em 27/03/2012, DJe 02/08/2012. 


\section{CAPÍTULO V - Remoção de conteúdo e sua consolidação nos tribunais}

A partir do desenvolvimento tecnológico e consequente carência legislativa, surgem dilemas sobre quais normas e princípios aplicar diante de um conflito envolvendo ilícitos na internet. Apresenta-se, portanto, a demanda por juízes técnicos que, para além do mero cumprimento de sua função social ${ }^{69}$, estejam abertos às mudanças, o que não significa ser suscetível a tudo, mas se colocar em estado de aprendizado.

\subsection{Pré-Marco Civil da Internet}

No REsp n ${ }^{\circ}$. 1.568.935 ${ }^{70}$, o autor R $\mathrm{H}$ da C L F ${ }^{71}$ demandou contra o Google, requerendo não apenas a exclusão de conteúdo publicado no Orkut, bem como o fornecimento dos endereços de $\mathrm{IP}^{72}$ (Internet Protocol), além da completa identificação dos responsáveis pelos comentários que abalaram seu casamento.

Inclusive, vaticinando o art. $19, \S 4^{\circ}$, do Marco Civil, o juízo de primeiro grau concedeu a antecipação de tutela pretendida, estabelecendo que:

"(...) a empresa ré, imediatamente, retire do seu 'blog' toda e qualquer referência ao nome do autor, e se abstenha de incluir outras, sob pena de multa diária de $\mathrm{R} \$$ 500,00 (quinhentos reais), devendo o mandado de citação e intimação se fazer acompanhar de cópias de fls. 28/29. Bem ainda, para também determinar à empresa ré que no prazo de 10 dias informe em juízo os dados cadastrais dos responsáveis pela postagem das afirmações mencionadas na petição inicial, bem como indique o nome do usuário, número do IP da máquina utilizada para

\footnotetext{
${ }^{69} \mathrm{O}$ juiz deve estar atento às transformações do mundo moderno, porque, ao aplicar o Direito, não pode desconhecer os aspectos sociais, políticos e econômicos dos fatos que lhe são submetidos. [...] a prestação jurisdicional deve ser exercida como instrumento de pacificação social e afirmação da cidadania, o que é facilmente verificado quando da ocorrência de sua aplicação célere e justa, consubstanciando-se, dessa forma, como um poderoso instrumento a serviço da população. Disponível em <http://www.tjdft.jus.br/institucional/imprensa/artigos/2010/a-funcao-social-damagistratura-na-contemporaneidade-juiza-oriana-piske>. Acesso em 04 abr. 2017.

${ }^{70}$ REsp 1568935/RJ, Rel. Min. RICARDO VILLAS BÔAS CUEVA, TERCEIRA TURMA, julgado em 05/04/2016, DJe 13/04/2016.

${ }^{71}$ Nome da parte abreviado em processo judicial.

${ }^{72} \mathrm{O}$ principal protocolo de comunicação da Internet, figurando como responsável por endereçar e encaminhar os pacotes que trafegam pela internet.
} 
postagem, data e horário da postagem, também sob pena de multa diária de $\mathrm{R} \$$ 500,00 (quinhentos reais)" 73 .

Contra a liminar, o Google recorreu, cujo agravo de instrumento the foi negado. Já em sentença, a antecipação de tutela foi confirmada, sendo julgado procedente o pedido ressarcitório, no valor de $\mathrm{R} \$ 40.000,00$ (quarenta mil reais). Ambas as partes apelaram da sentença, que foi confirmada pelo TJ-RJ, sobrevindo o REsp em tela.

O Min. Ricardo Villas Bôas, em seu relatório, realizou a distinção entre provedores de acesso e conteúdo, entendendo que o Google se enquadra apenas como provedor de serviços, quais sejam correio eletrônico, hospedagem e conteúdo. Destaca, ainda, a jurisprudência consolidada no Superior Tribunal de Justiça quanto à responsabilidade do provedor depender da existência ou não de um mecanismo de controle de conteúdo.

Porquanto, não havendo esse controle, a responsabilização só será vindicada se, após a notificação judicial para a retirada, o provedor não obedecer. No entanto, no referido REsp, sustenta o excelso Ministro, havendo ferramenta de controle, "o provedor de conteúdo torna-se responsável pelo que for publicado independentemente de notificação". Por outro lado, caso a publicação se dê em portais de notícias cuja revisão de textos é obrigatória, a responsabilidade é clara, entende Villas Bôas.

As controvérsias pré-Marco Civil também não encontravam solução simples porque havia certa dúvida quanto à natureza da notificação necessária para tornar indisponível o conteúdo, ou seja, se bastaria um pedido administrativo formulado pelo titular das informações, ou se imprescindível a ordem judicial.

Nessa linha, as reclamações realizadas extrajudicialmente, em alguma medida, ganharam força, reconhecida como louvável a iniciativa do

\footnotetext{
${ }^{73}$ REsp 1568935/RJ.
} 
provedor de conteúdo, que mantém em redes sociais, um canal para denúncias ${ }^{74}$.

Com efeito, Nancy Andrighi complementa:

É crucial que haja a efetiva adoção de providências tendentes a apurar e resolver as reclamações formuladas, mantendo o denunciante informado das medidas tomadas, sob pena de se criar apenas uma falsa sensação de segurança e controle.

No entanto, mais adiante, o Marco Civil não obrigou o provedor de conteúdo a criar uma ferramenta de denúncia, um canal de comunicação direta com o usuário, dentro da plataforma. E, hoje, sabe-se que havendo controvérsia, a avaliação do juiz é determinante para responsabilizar o provedor de conteúdo pelas informações publicadas.

\subsection{Pós-Marco Civil da Internet}

Hoje, após a edição da lei 12.965/14, conhecida como Marco Civil da Internet, o Judiciário repete alguns posicionamentos adotados anteriormente à vigência da lei e outros que foram pacificados graças ao art. 19 e seguintes da referida norma.

Em uma decisão curiosa $^{75}$, entre o Google e o interessado pela remoção do conteúdo, o magistrado cuidou de controvérsia sobre a divulgação de conteúdo em sites de terceiros, mas disponibilizados pela empresa Ré.

Ressalte-se, ainda, que, de acordo com os conceitos apresentados no capítulo anterior e com o Marco Civil da Internet, o Google é um provedor de aplicações, que atua como ferramenta de pesquisa (sua principal função), como correio eletrônico (Gmail), mas também como provedor de conteúdo (YouTube, Blogger, entre outros). No caso apresentado a seguir, a empresa atuava como ferramenta de pesquisa.

\footnotetext{
${ }^{74}$ REsp 1.308.830/RS, Rel. Mina. Nancy Andrighi, Terceira Turma, julgado em 8/5/2012, DJe 19/6/2012.

${ }^{75}$ TJ-RJ, Agravo de instrumento ${ }^{\circ}$. 0000918-43.2016.8.19.0000/RJ, Rel. Desembargador Sergio Wajzenberg, Rio de Janeiro, 03 mai. 2016.
} 
O Google permite pesquisas em seu indexador, mas não possui mecanismos que possibilitem prévio controle do conteúdo que é disponibilizado em sua aplicação.

O conteúdo analisado pelo magistrado se trata de matéria jornalística publicada a respeito do autor, insinuando os negócios que celebra no exterior, além do seu relacionamento com a Polícia Federal brasileira.

Destaca, ainda, que a CRFB/88, no art. 5, X, elenca como direitos fundamentais a inviolabilidade da vida privada, da honra e da imagem das pessoas. Recaindo a responsabilidade de justa indenização sobre aquele que infringir tais direitos. Por outro lado, a Constituição Cidadã prevê a liberdade de manifestação do pensamento, no art. $5^{\circ}$, IV, cujo objetivo é impedir a censura e garantir o acesso à informação.

Em princípio, há um conflito entre os valores constitucionais acima, demandando ponderação e análise técnica por quem é dotado de competência, o juiz. Como já visto, a responsabilidade civil dos provedores de aplicações na internet, seja pelos próprios atos, seja pelos atos de terceiros, varia conforme o tipo de serviço prestado e os deveres a ela inerentes.

É de conhecimento que o art. 19 do Marco Civil prevê que o provedor de aplicações não é responsabilizado pelos danos causados por conteúdo publicado por terceiros - justamente por ser onerosa a obrigação de controle prévio, além de cercear de plano a liberdade de expressão.

Entretanto, dizer que, via de regra, o provedor de aplicações não será responsabilizado por conteúdo de terceiros não é dizer que o provedor nunca será responsabilizado. É sabido que o Marco Civil estabelece a responsabilidade subsidiária no caso de o provedor não adotar as medidas necessárias para, dentro do prazo comandado por decisão judicial, remover o conteúdo indicado como violador de direitos. Excetuados os casos em que o material apontado esteja relacionado a dados sensíveis, hipótese em que a 
retirada deve ocorrer após o recebimento da notificação pelo interessado, nos termos do art. 21, do Marco Civil.

O julgador se baseou na existência de profissões que exigem maior exposição das pessoas, em que se enquadra a profissão do autor, no caso, empresário, ficando sujeito a críticas no exercício de sua profissão, mas também em relação aos atos praticados em locais públicos.

Feita a observação acima, no entanto, não é possível admitir que sejam ventiladas informações inverídicas capazes de desonrar, degradar a vida privada de qualquer indivíduo, seja ele pessoa pública ou não. Em se tratando de pessoa pública, desde que o conteúdo tenha natureza informativa ou possua fundamento, é claro que o direito à privacidade será mitigado - o que não se verifica no caso em tela.

O juiz de primeira instância entendeu pela retirada dos resultados que direcionavam para as matérias jornalísticas, no buscador do Google, sob pena de multa diária - nascendo neste momento a responsabilidade do provedor de aplicações.

Como se viu, o Google não apresentou quaisquer fatos ou documentos que fundamentassem a permanência dos resultados obtidos por qualquer usuário que acessasse a plataforma, restando evidente a ilicitude do conteúdo e distante do caráter informativo inerente à liberdade de informação. Por essas razões, o Des. Sergio Wajzenberg entendeu pela manutenção da sentença de piso e pela devida remoção dos links que levavam ao conteúdo, embora a Ré não fosse a provedora da informação, mas por dispor dos meios para a retirada de seu indexador.

Note-se que o provedor de aplicações não foi responsabilizado pelo ilícito praticado pelo provedor de informações quando da publicação de matéria jornalística, mas, tão somente, foi impelido a remover o conteúdo publicado pelo jornal (provedor de informações). Conquanto, a partir da decisão determinando tornar indisponível o conteúdo apontado como 
infringente, nasceu para o provedor de aplicações, neste caso, o Google, a responsabilidade de remover o conteúdo, nos termos do art. 19, do Marco Civil. 


\section{Conclusão}

Ao longo deste trabalho, foi possível perceber que, apesar de não ser simples a tarefa de tutelar a privacidade, é preciso. Não é tarefa simples, pois se trata de um direito que confronta interesses de alta complexidade. A privacidade não deve ser tratada como um direito patrimonial, nem como o direito a estar sozinho.

A privacidade deve ir além da noção de estar sozinho: é a tutela que preza pela proteção de dados pessoais e conteúdos sensíveis que orbitam cada indivíduo. Nas palavras de Doneda, "o discurso sobre a privacidade cada vez mais concentra-se em questões relacionadas a dados pessoais e, portanto, informação"76.

Informação é sinônimo de conhecimento. Hoje, a rigor, quem tem conhecimento nas mãos possui poder. E poder, por seu turno, é sinônimo de controle. Privacidade deve ser traduzida como o direito ao controle das próprias informações. Compreende-se por tutela a este direito, determinar quais dados entram e quais saem da esfera de um indivíduo ou de um grupo.

$\mathrm{Na}$ medida em que esta esfera é vilipendiada por terceiros, surge, portanto, a necessidade de repará-la. Em muitos casos envolvendo a indisponibilização de conteúdo, a prestação pecuniária não é suficiente. Por vezes, o cumprimento de uma obrigação de dar, fazer ou deixar de fazer é mais satisfatória que a prestação pecuniária. Faz-se mister evocar o princípio da primazia da tutela específica na execução previsto nos arts. 497 e seguintes do CPC.

Art. 497. Na ação que tenha por objeto a prestação de fazer ou de não fazer, o juiz, se procedente o pedido, concederá a tutela específica ou determinará providências que assegurem a obtenção de tutela pelo resultado prático equivalente. Parágrafo único. Para a concessão da tutela específica destinada a inibir a prática, a reiteração ou a continuação de um ilícito, ou a sua remoção, é irrelevante a demonstração da ocorrência de dano ou da existência de culpa ou dolo.

\footnotetext{
${ }^{76}$ DONEDA, Op. cit., p.151.
} 
Art. 498. Na ação que tenha por objeto a entrega de coisa, o juiz, ao conceder a tutela específica, fixará o prazo para o cumprimento da obrigação. Parágrafo único. Tratando-se de entrega de coisa determinada pelo gênero e pela quantidade, o autor individualizá-la-á na petição inicial, se lhe couber a escolha, ou, se a escolha couber ao réu, este a entregará individualizada, no prazo fixado pelo juiz.

Art. 499. A obrigação somente será convertida em perdas e danos se o autor o requerer ou se impossível a tutela específica ou a obtenção de tutela pelo resultado prático equivalente.

Art. 500. A indenização por perdas e danos dar-se-á sem prejuízo da multa fixada periodicamente para compelir o réu ao cumprimento específico da obrigação.

Nesta linha, impor ao provedor responsável que, ao menos, se preste a analisar a indicação de um conteúdo que viole a dignidade do titular daquelas informações, mediante notificação extrajudicial, ou por meio de um canal de comunicação plataforma-usuário, é o que se espera da futura lei de proteção de dados.

O Marco Civil da Internet, apesar de significativo passo inicial para o tema, deixou de lado aspectos caros para a segurança e privacidade no âmbito da tecnologia. Como destaca o professor da USP e doutor em Direito Civil pela instituição, Eduardo Tomasevicius Filho, “embora o Marco Civil da Internet tenha sido bastante festejado por ser a primeira lei do mundo a disciplinar os direitos e deveres dos usuários da rede, não se perceberão mudanças substanciais" 77 .

E, mais adiante, complementa:

(...) são muitas as deficiências e insuficiências do Marco Civil da Internet, mesmo depois da revisão do projeto inicial por meio da aprovação do texto substitutivo. Afinal, toda lei aprovada tem a finalidade de inovar o ordenamento jurídico, acrescentando normas necessárias à regulação dos comportamentos, eliminando aquelas que não mais atendem às necessidades sociais. $\mathrm{O}$ primeiro ponto a ser observado é a redundância de várias de suas disposições, que repetem, com insuficiência, o que já consta na Constituição Federal. Nenhuma "ginástica hermenêutica" é capaz de permitir ao operador do direito a obtenção de significado adicional ${ }^{78}$.

\footnotetext{
77 TOMASEVICIUS FILHO, Eduardo. Marco Civil da Internet: uma lei sem conteúdo normativo. Estudos Avançados da Universidade de São Paulo, vol.30, n.86, São Paulo: jan/abr. 2016, p. 276.

${ }^{78}$ Ibid., p. 279 .
} 
O objetivo é que, em alguma medida, o legislativo elabore normas mais efetivas no campo das tecnologias e apresente outras saídas. A primeira delas seria a aprovação do PL $\mathrm{n}^{\circ}$. 5.276/2016, que dispõe acerca do tratamento de dados pessoais. Como segunda medida, desenvolvesse de forma técnica e precisa determinados dispositivos, a fim de evitar retrocessos.

Ao Judiciário, resta-lhe a apreciação das demandas envolvendo a requisição para remoção de conteúdo ofensivo, refreando os abusos por parte dos provedores de informações, responsabilizando os provedores de conteúdo quando for o caso, tornando equânime os interesses e garantindo a proteção aos direitos da personalidade, neste caso, a privacidade. 


\section{Referências bibliográficas}

ANTONIALLI, Dennys et al.. O que são dados pessoais? Disponível em $<$ http://www.internetlab.org.br/pt/opiniao/especial-o-que-sao-dadospessoais/>. Acesso em 16 mar. 2017.

ANTONIALLI, Dennys et al.. Big data: quais proteções os titulares de dados têm a sua disposição? Disponível em: < http://www.internetlab.org.br/pt/opiniao/especial-em-um-mundo-de-bigdata-quais-tipos-de-controle-temos-em-relacao-a-nossos-dados/>. Acesso em 16 mar. 2017.

BDINE JÚNIOR, H. C. Responsabilidade civil do veículo de comunicação por atos próprios. In: SILVA, R.B.; SANTOS, M.J. (orgs). Responsabilidade Civil na internet e nos demais meios de comunicação. São Paulo: Saraiva, 2007. 494 p.

BIONI, Bruno Ricardo. Xeque-mate: o tripé de proteção de dados pessoais no xadrez das iniciativas legislativas no Brasil. Disponível em < https://gpopai.usp.br/wordpress/wp-

content/uploads/2016/07/XEQUE_MATE_INTERATIVO2.pdf>. Acesso em 16 mar. 2017.

CAVALIERI FILHO, Sergio. Programa de Responsabilidade Civil. $11^{\mathrm{a}}$ ed.. São Paulo: Atlas, 2014. 648 p.

COTS, Márcio; OLIVEIRA, Ricardo. Sistemática de retirada de conteúdo da internet piorou com o Marco Civil. Disponível em $<$ http://www.conjur.com.br/2014-set-10/sistema-retirada-conteudo-internetpiorou-marco-civil>. Acesso em 30 mar. 2017.

DIDIER JR., Fredie. Curso de Direito Processual Civil. 17ed. v. 1. Salvador: Juspodivm, 2015. 786 p.

DONEDA, Danilo. Da privacidade à proteção de dados pessoais. Rio de Janeiro: Renovar, 2006. 439 p.

GONÇALVES, Carlos Roberto. Direito Civil Brasileiro: Parte Geral. 10 ed.. São Paulo: Saraiva, 2012. 561 p.

HELBING, Dirk et al. Will Democracy Survive Big Data and Artificial Intelligence? Disponível em: < https://www.scientificamerican.com/article/ will-democracy-survive-big-data-and-artificial-intelligence/> Acesso em 29 mar. 2017. 
LEMOS, Ronaldo. Ofensas na internet não justificam censura. Revista Tribuna do Advogado, Rio de Janeiro, n. 561, p.16-17, Out. 2016.

LEONARDI, Marcel. Responsabilidade civil dos provedores de serviços de internet. São Paulo: Juarez de Oliveira, 2005. 203 p.

LEONARDI, MARCEL. "Responsabilidade dos provedores de serviços de internet por atos de terceiros". In: SILVA, R.B.; SANTOS, M.J. (orgs). Responsabilidade Civil na internet e nos demais meios de comunicação. São Paulo: Saraiva, 2007, 494 p.

MACHADO, Joana de Moraes Souza. A tutela da privacidade no controle de dados pessoais no Direito brasileiro. Disponível em < http://www.ojs.ufpi.br/index.php/raj/article/viewFile/4671/2694>. Acesso em 23 mar. 2017.

MENDES, Gilmar Ferreira; BRANCO, Paulo Gustavo Gonet. Curso de direito constitucional. $9^{\mathrm{a}}$ ed.. São Paulo: Saraiva, 2014. 1446 p.

MENDES, Nádia. É proibido publicar. Revista Tribuna do Advogado, Rio de Janeiro, n. 563, p.30-31, Fev. 2017.

MULHOLLAND, Caitlin. Responsabilidade civil indireta dos provedores de serviço de internet e sua regulação no marco civil da internet. Disponível em<http://www.conpedi.org.br/publicacoes/c178h0tg/vwk790q7/dTa7488 W12NDA0SJ.pdf $>$. Acesso em 28 mar. 2017.

NOGUEIRA, André Fontoura. Marco Civil da Internet: Desafios à sua efetivação entre a sociedade e o poder econômico. Disponível em < http://portaldeperiodicos.unibrasil.com.br/index.php/anaisevinci/article/vie w/923>. Acesso em 29 mar. 2017.

RODOTÀ, Stefano. A Vida na Sociedade da Vigilância: A privacidade hoje. Maria Celina Bodin de Moraes (Org.). Rio de Janeiro: Renovar, 2007. $382 \mathrm{p}$.

SCHREIBER, Anderson. Direitos da Personalidade. São Paulo: Atlas, 2013. $296 \mathrm{p}$.

SILVA, R.B. Sistema protetivo dos direitos da personalidade. In: SILVA, R.B.; SANTOS, M.J. (orgs). Responsabilidade Civil na internet e nos demais meios de comunicação. São Paulo: Saraiva, 2007. 494 p.

STJ, REsp n. 1192208/MG, Rel. Mina. Nancy Andrighi, Brasília, 27 mar. 2012. 
STJ, REsp n. 1308830/RS, Rel. Mina. Nancy Andrighi, Brasília, 8 mai. 2012.

STJ, REsp n. 1406448/RJ, Rel. Mina. Nancy Andrighi, Brasília, 15 out. 2013.

STJ, AgRg no AREsp n. 479.351/SP, Rel. Min. Sidnei Beneti, Brasília, 24 abr. 2014.

STJ, AgRg no AREsp n. 642.400/PR, Rel. Mina. Maria Isabel Gallotti, Brasília, 12 mai. 2015.

STJ, AgRg no AREsp n. 681.413/PR, Rel. Min. Raul Araújo, Brasília, 08 mar. 2016.

STJ, REsp n. 1568935/RJ, Rel. Min. Ricardo Villas Bôas Cueva, Brasília, 05 abr. 2016.

TJ-RJ, Agravo de instrumento $\mathrm{n}^{\mathrm{o}}$. 0000918-43.2016.8.19.0000/RJ, Rel. Desembargador Sergio Wajzenberg, Rio de Janeiro, 03 mai. 2016.

TOMASEVICIUS FILHO, Eduardo. Marco Civil da Internet: uma lei sem conteúdo normativo. Estudos Avançados da Universidade de São Paulo, São Paulo, vol.30, n.86, p. 269-285, jan./abr. 2016. 